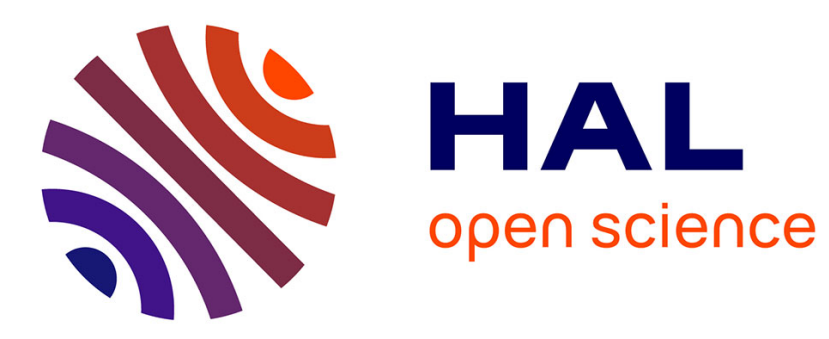

\title{
Dust Growth by RF Sputtering
}

\author{
Blake Churton, Lénaïc Couëdel, Alexander A. Samarian, Maxime Mikikian, \\ Laifa Boufendi
}

\section{To cite this version:}

Blake Churton, Lénaïc Couëdel, Alexander A. Samarian, Maxime Mikikian, Laifa Boufendi. Dust Growth by RF Sputtering. Fifth International Conference on the Physics of Dusty Plasmas, May 2008, Ponta Delgada, Azores, Portugal. pp.187, 10.1063/1.2996830 . hal-00328152

\section{HAL Id: hal-00328152 https://hal.science/hal-00328152}

Submitted on 9 Oct 2008

HAL is a multi-disciplinary open access archive for the deposit and dissemination of scientific research documents, whether they are published or not. The documents may come from teaching and research institutions in France or abroad, or from public or private research centers.
L'archive ouverte pluridisciplinaire HAL, est destinée au dépôt et à la diffusion de documents scientifiques de niveau recherche, publiés ou non, émanant des établissements d'enseignement et de recherche français ou étrangers, des laboratoires publics ou privés. 


\title{
Dust Growth by RF Sputtering
}

\author{
B. Churton*, L. Couëdel ${ }^{*, \dagger}$, A.A. Samarian*, M. Mikikian ${ }^{\dagger}$ and \\ L. Boufendi ${ }^{\dagger}$ \\ * School of Physics, The University of Sydney, NSW 2006 ,Australia \\ ${ }^{\dagger}$ GREMI, CNRS/Université d'Orléans, 14 rue d'Issoudun, BP6744, 45067 Orleans Cedex 2,
}

France

\begin{abstract}
The effect of the dust particle growth by RF sputtering on glow discharge has been investigated. It has been found that the growth of dust particles modifies the electrical characteristics of the discharge. In particularly, the absolute value of the self-bias voltage decreases during the particle growth due to the electron losses on the dust particles. To find the correlation between the dust growth and the self bias evolution, dust particles have been collected at different times. The dust particle growth rate is found to be linear.
\end{abstract}

Keywords: Dust particles, growth, complex plasma

PACS: $52.27 . \mathrm{Lw}$

Complex plasmas are gaining in importance, as the terrestrial use of plasmas increases and as complex plasma's role in astrophysics is further explored. Growth mechanisms are well understood in the case of chemically active plasmas [1], whilst few studies of particle growth by RF sputtering have been undertaken [2,3]. Dust particle growth
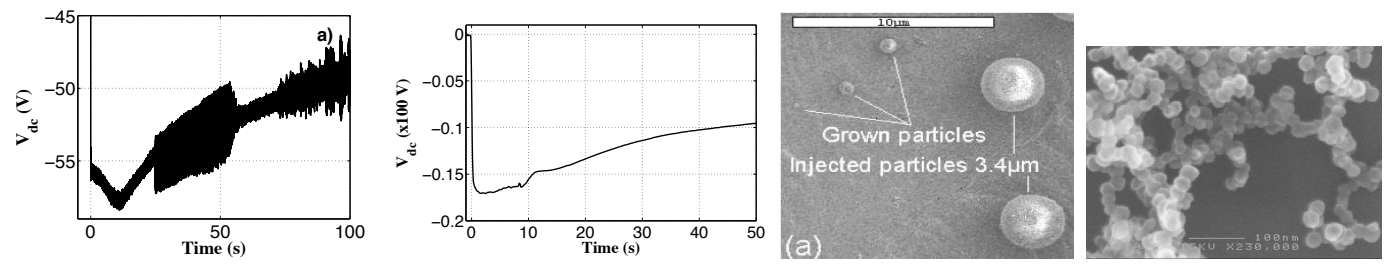

FIGURE 1. From the left to the right: evolution of the self-bias voltage during the dust particle growth in the PKE-Nefedov reactor; Evolution of the self-bias voltage during the dust particle growth in the ComPLExS reactor; dust particles collected in the PKE-Nefedov reactor; dust particles collected in the ComPLExS reactor

by RF sputtering ( in the PKE-Nefedov reactor and the ComPLExS reactor), and its effects on the discharge parameters are thus investigated in glow discharges. Sputtering of a polymer layer of melamine formaldehyde deposited on the electrodes was used to produce dust particles.

The presence of dust is known to cause a decrease (in absolute value) of the self bias $V_{d c}$ [4]. As can be seen (Fig.1), in both experiments, $\left|V_{d c}\right|$ decreases clearly indicating the growth of dust particles. Dust particles were collected at different discharge times in the ComPLExS reactor and analyzed using SEM. Four samples have been collected: for a running time of $t \sim 10 \mathrm{~s}$ before the fast increase of $V_{d c}$. The mean radius is $r_{d} \sim 15$ $\mathrm{nm}$. For a running time of $t \sim 20 \mathrm{~s}$ at the end the fast increase of $V_{d c}$. The mean radius is $r_{d} \sim 24 \mathrm{~nm}$. For running time of $t \sim 30 \mathrm{~s}$. The mean radius is $r_{d} \sim 32 \mathrm{~nm}$. For a running 

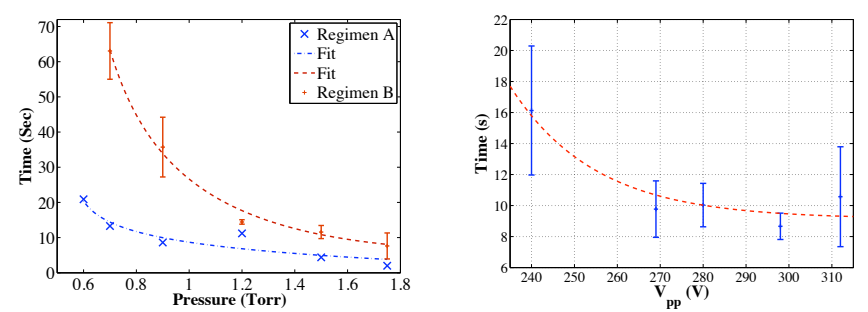

FIGURE 2. Growth time (5\% increase of the self bias above its minimum value) as a function of pressure (Left) and RF voltage (Right) in the ComPLExS reactor

time of $t>120 \mathrm{~s}$. The mean radius is $r_{d} \sim 100 \mathrm{~nm}$. However, there is a large dispersion. A possible explanation is the existence of many generation of dust particles. It has been found that the dust particle growth rate tends to be linear in accordance with the the results of Ref.[3].

Finally, $\left|V_{d c}\right|$ was measured for different operating pressures and powers and the time needed to observed an effect due to the dust particle growth recorded (Figs.2 and 3). $\left|V_{d c}\right|$ is found to decrease faster for higher pressures. Moreover, it has been found that increasing the power (or RF voltage) results in a decrease in the time taken for the self bias to increase; however saturation occurs (limit above which no further increase in the growth rate is observed). The dust growth is faster for high pressure and/or high power. An impurity effect was observed: a cleaner chamber results in higher growth rates.

To conclude, the growth of dust particles has been investigated in both PKE-Nefedov reactor and ComPLExS reactor. This growth modifies the electrical characteristics of the discharge: $\left|V_{d c}\right|$ decreases during the particle growth due to electron losses on dust particles.
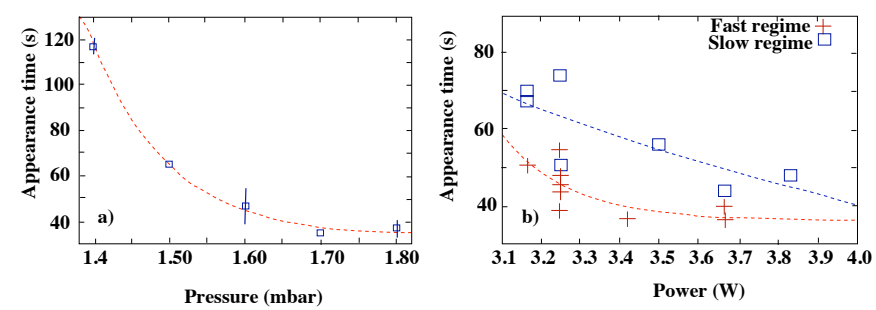

FIGURE 3. Growth time (appearance of instabilities (strong amplitude variations) in the signal) as a function of pressure (Left) and power (Right) in the PKE-Nefedov reactor

\section{REFERENCES}

1. A. Bouchoule, Dusty Plasmas: Physics, Chemistry and Technological impacts in Plasma Processing, Wiley, New York, 1999.

2. D. Samsonov, and J. Goree, J. Vac. Sci. Technol. A 17, 2835 (1999).

3. C. Dominique, and C. Arnas, J. Appl. Phys. 101, 123304 (2007).

4. M. Cavarroc, M. C. Jouanny, K. Radouane, M. Mikikian, and L. Boufendi, J. Appl. Phys. 99, 064301 (2006). 